\title{
Corporate Culture in Service Companies that Support Knowledge Sharing
}

\author{
Andrea Bencsik, Silvia Tóbiás Kosár, Renáta Machová \\ J. Selye University, Komárno, Slovak Republic
}

\begin{abstract}
The corporate significance of knowledge has already been proven on the basis of several research findings. Manufacturing companies play an important role in development of knowledge-based society. The added value provided by service companies is essential in knowledge creation. The success of knowledge sharing is influenced by many internal and external factors. The quality of services also depends on knowledge strategy of the company. We have focused primarily on the analysis of knowledge creation of businesses providing services in different cultures (sometimes with similar cultural features). We have analysed the corporate culture of knowledge-based organizations, as well as the corporate practice of knowledge supporting organizations in the Slovak-Hungarian border.
\end{abstract}

Keywords: knowledge sharing, corporate culture, knowledge, knowledge management

JEL Classification: D83, J53, M12, M54

\section{Introduction}

At the beginning of the $21^{\text {st }}$ century with the emergence of new paradigms of knowledge, the examination of knowledge has become widespread not only on theoretical, but practical level as well. According to Boisot, the emergence of economic systems is expected, where knowledge does not only act as a medium of exchange, but will become an essential element of the system (Bakacsi, 2000). The theory also supports the fact that the main focus of effective economic growth is the growth of knowledge-intensive sectors, especially the service sector (Moerel, 2008). This tendency can be detected not only in the countries of Western Europe, but in different sectors of the Central and Eastern European economies. This fact is supported by the results of the research conducted in Slovakia in 2010. The main objective of this research was to map the possibilities of knowledge creation and spreading of knowledge among different types of regions. The importance of knowledge exchange is supported by an intensive cooperation of local organizations and research institutions, as well as the corporate co-operations aimed at gaining and sharing knowledge about the industrial production (Buček, 2010).

The processes related to knowledge as a production factor have reshaped and are still forming the functioning of the economy (Lengyel, 2010). A factor of production known as Knowledge-intensive service (KIS) activity contains a high level knowledge component. On the other hand, the knowledge-intensive business services $\mathrm{KI}(\mathrm{B}) \mathrm{S}$, a subcategory of KIS, as described by Strambach (2008) is a process of cumulative learning, which is created by in- 
depth interactions between market participants, and a process of problem solving to adopt knowledge to the needs of clients (Máté-Kun-Fenyvesi, 2016). The goal of globalization is to develop a knowledge-based economy, as well as get closer the isolated places and different parts of the country with the help of communication (Dobrotková, 2008). The knowledgebased economy is an economic structure, where production, distribution and utilization of knowledge-intensive products and services are crucial. It is also a segment of the market environment in which the majority of added value is formed by knowledge (Báger, 2008). The purpose of knowledge management is to map, collect, organize and utilize the knowledge accumulated in the organization.

\subsection{Knowledge}

No matter knowledge is recognized as a basic resource by entrepreneurs and individuals, the importance and dissemination of knowledge has not always been recognized. Many researchers have highlighted the spill-over effect of knowledge (Döry, 2005), but dissemination and ensuring knowledge requires a complex approach. The complete or partial processes related to knowledge as an enhanced production factor have reshaped and are currently shaping the economy (Lengyel, 2010).

The representatives of organizational sciences describe the importance of knowledge as a tool of problem solving. According to Drucker, knowledge is a set of solution-oriented information (Drucker, 1993; Yi-Chun - Yen-Chun, 2009). It is a valuable resource for organizations and the society to acquire further necessary goods (Tomka, 2009). According to other representatives, knowledge is a personal skill, which can help the individual to complete tasks efficiently. Knowledge is not only an ability of an individual, but a result of interactions as well (Wilkesmann-Rascher, 2004).

As organizations are in continuous interaction with their environment, the economic and quantitative approach essential. We disagree with the work of authors, who question the understanding of knowledge in terms of corporate indicators. Knowledge is an essential resource of the organization beside work, capital and natural resources. It involves the necessary skills, knowledge, experience, emotions, values and intuition essential to achieve success. It is an intangible asset, and the value of it is increasing by sharing and dissemination, as well its importance can be evaluated only later (Lucko-Trauner, 2005). When analysing knowledge as an economic asset, its microeconomic explanation becomes necessary. In microeconomic terms it plays a role in the relationship between the seller and consumer, as we assume that there is relevant information behind their decision making. We can say that the players of the economy use their knowledge rationally (Lundwall, 2004). If we think about knowledge as an asset, it will appear in form of a competence in production process or the supply chain. Knowledge can also become a medium of exchange (Rehák, 2009). Knowledge-sharing is often implemented through community services between the companies and consumers, because the joint use of tools and services cannot be realized without an exchange of information related to them.

\subsection{Organizational culture and the knowledge-based organization}

According to Csath (2008), the management of organizational knowledge becomes effective when it is integrated into the processes, traditions and habits (corporate culture) of the organization. In this interpretation, an important feature of culture is that it applies not 
only to individuals but the whole community. The cohesive force between the organizational players and the organization is formed with the help of knowledge. It is difficult to change and shape (Csath, 2008).

According to Schultz (1995), the organizational culture can be interpreted as a view on the organization. Three types of organizational culture can be differentiated: rationalist, functionalist and the symbolism. According to rationalist view, culture is an effective tool to reach objectives, while it can be interpreted as a community system by the functionalist approach. According to symbolism, the culture can be considered as a system of people. It is examining the relationship between the employees and the organization. The purpose of learning and culture is primarily to secure the survival of the company (Schultz, 1995). The elements of culture can be considered all those things the employees get in contact with in everyday process e.g. traditions, behavioural norms, thinking, knowledge, language and objects (Drjenovszky I., 2005).

Schein described organizational culture as a series of layers: objects, values, norms and convictions. The objects are associated with external manifestation of culture. These can be easily observed, described but easily influenced. The values and norms are partly conscious, but can be partially changed by leadership. Convictions/Constipations are the deepest level of culture, they involve the unconscious. For representatives of culture they can be interpreted as opinion and thoughts. They are difficult to be defined by the management. The arrows in figure point to influence of different levels of culture on each other (Schein, 1992; Lukášová, 2010) (Seres-Huszárik, Józsa, Tóth, Zs.,2017).

There are several models examining the organizational culture, which examine not only the company features, but the development opportunities of the organization as well. We consider the Quinn model (1988) as a basic model of organizational culture that contributes to the success of knowledge management processes. Quinn studied the culture values that explain the efficiency of the organization, and analysed them in relation to two dimensions. The focus of the organization can be inward or outward; regarding the management control it can be flexible and strictly controlled. Quinn refers to this model as a model of competing values, because he examined not only the most important values of leadership, but also efficiency as a characteristic feature as well. The organization focusing inwards concentrates on internal processes and the players in the organization. The organization with an outward focus concentrates on adapting to the external environment. The flexible organization provides more flexibility and freedom in decision making, while strict control means strict regulations. We can differentiate four basic types of culture (Bakacsi, 2010), (Mura, Ključnikov, Tvaronavičiene, Androniceanu, 2017):

1. Supportive culture - mutual trust and responsibility, participation and cooperation are important. The co-operative behaviour and team spirit is important, the opportunity for individual development and self-realization are essential. The focus is on the development of human resources. The communication is informal, and the members of the organization are committed to goals and processes.

2. Rule-oriented culture - respect for formal positions, rationality and formality of processes. Stability and balance in focus; characterized by hierarchical company structure. There is mainly written form of communication in these types of organizations.

3. Target-oriented culture - the main characteristics are the rational planning, focus on performance, limited access to information and the central role of the leader. Mainly oral communication is practiced in the organization. 
4. Innovation-oriented culture - characterized by constant focus on the external environment; there is continuous innovation, experimentation and risk taking is in the focus of the organization. The key elements are: growth, access to environmental resources and flexibility. The dynamism of the organization is ensured by creative problem solving, competitive spirit, focus on future, free and unrestricted flow of information, continuous training and learning.

\section{Problem Formulation}

How culture of the organization will support the knowledge management? First we should characterize the relationship between the actors of culture, knowledge sharing and management of knowledge. In our opinion the key player of knowledge supporting organizational culture is the individual, who possesses knowledge in the organization. The primary task of the leader and the management is hiring and retaining employees, who will support the knowledge-based organizational culture. It is also necessary to manage and deal with knowledge in system. This can be achieved by increasing the level of qualification of company employees. The leaders have to develop a business environment, where employees will be motivated to acquire new knowledge. The single elements of culture, as well as the objectives of individual and the organization should be considered. The employees should be motivated to share the acquired knowledge (Mesároš, 2005).

The leaders have no easy task to develop a knowledge-based organizational structure. Both national and the organizational cultural knowledge will influence the thoughts, actions, perception and feelings of individuals and groups in the process of knowledge transfer. In the appropriate organizational culture the individuals will share their knowledge not because they are forced to do that, but they have the appropriate work environment and can act in accordance of their beliefs. The focus on knowledge processes will change the nature of organizational culture. It is necessary to develop an efficient knowledge management system, where sharing, preservation and development of knowledge will become a natural phenomenon. On the other hand, it is necessary to manage the behavioural patterns and habits that underpin the existing cultural aspects. (Müller - Nessler, 2011, Bencsik- Stifter Sólyom, 2012).

\subsection{Methodology}

The target group of questionnaire survey were the organizations with registered office or headquarters in towns and villages of the examined Slovak-Hungarian border region. The target area of research were Győr-Moson-Sopron and Komárom-Esztergom counties, while in Slovakia it was represented by districts of Dunajská Streda, Komárno and Nové Zámky. The business register of countries and databases of statistical office were used to collect the sample data.

We applied random sampling technique, the method of stratified sampling. We considered this method as advantageous as it contains a multi-stage process, which can be used to select the sample elements from target group according to expectations we set. Sampling was a two-step process. We divided the group (companies registered in the border region of Hungary and Slovakia) into subgroups. These subgroups were formed by various neighbouring administrative units. With the help of the layering variable (towns and villages of the targeted research area), the sample elements were selected by a random sampling 
method. Only those companies that are registered in the targeted area could enter the questionnaire survey sample. To conduct relevant survey, the sole-proprietors were not included in the sample. The sample is formed by 630 companies; 300 of them operating in Hungary, 330 operate in Slovakia.

\subsection{Statistical methods of data analysis}

We applied univariate, two-and multivariate analyses in our research. Univariate analyses are the starting point for statistical research, where the variables are analysed independently. The aim of two-variable analysis is to provide a concise, quantitative analysis of the relationship between the data and criteria. Multivariate analyses focus on examining dependencies between the variables, and determine the strength and nature of this relationship (Bálint, 2009). The summary of methods we applied is the following (Malhotra, 2002):

1. Average - it is used in case of data collected by interval and ratio scales; it shows the arithmetic mean of data,

2. Deviation - a measure of difference between the observed value of a variable and some other value, often that variable's mean,

3. Cluster analysis - is a dimension-reducing process by which data blocks - observation units - can be classified into relatively homogeneous groups. Its aim is to show that there are groups that are more similar to each other than members of other groups,

4. Analysis of variance - analyses the difference between the averages of two or more variables. It belongs to a group of explanatory models, which is examining the impact of an independent group on dependent variables. Its objective is to group the observed units into a relatively homogeneous group.

5. Cross-panel analysis - examines the relationship between two or more variables. The contingency table is based on the frequency distribution of variables. As a result of the investigation it is possible to say whether there is a correlation between two nominal or ordinal variables.

\section{The practical analysis of knowledge sharing}

According to Quinn, the organizations are divided into four groups based on their flexibility, stability and their external vs internal orientation. Dynamic, internally-oriented companies are part of the supporting culture, characterized by a friendly environment. This company builds on trust, tradition and loyalty, where teamwork is essential. Its main objective is the organizational development. The dynamic, externally-oriented companies fall into a category of innovation-oriented culture, which is designed to create new resources and promote growth. These organizations are motivated by dynamism, creativity and entrepreneurial spirit. They are characterized by risk-taking, openness to new opportunities and challenges. Its tools are innovation and experimentation. The culture supporting knowledge transfer requires people-centred approach, as well as requires openness to new challenges and innovative solutions.

The questionnaire survey examined the characteristics of the organizational culture, where the respondents had to rank the listed options, where $1=$ the most characteristic and $4=$ the least characteristic option. The average of the respondents and the standard deviation is presented in the following table. 
The average and deviation of answers based on Quinn description of cultures

\begin{tabular}{|c|c|c|}
\hline Variable & Average & Deviation \\
\hline Family atmosphere & 2,89 & 1,235 \\
\hline Dynamic, competing place & 2,19 & ,912 \\
\hline Result orientation & 2,83 & ,942 \\
\hline Formal culture and leadership & 2,07 & 1,103 \\
\hline Supporting leadership & 2,22 & 1,179 \\
\hline Result-oriented, aggressive leadership & 2,22 &, 888 \\
\hline Leadership supporting risk-taking, innovation and competition & 2,55 & 1,162 \\
\hline Managing, organizing and efficient leadership & 2,99 & 1,045 \\
\hline Managing employees via teamwork, consensus and involvement & 2,61 & 1,205 \\
\hline $\begin{array}{l}\text { Managing employees based on independence, risk-taking, innovation } \\
\text { and uniqueness }\end{array}$ & 2,45 & 1,054 \\
\hline $\begin{array}{l}\text { Managing employees based on competition, high expectations and } \\
\text { performance }\end{array}$ & 2,25 & 1,075 \\
\hline $\begin{array}{l}\text { Managing of employees based on work safety, conformity, predictability } \\
\text { and permanent relationships }\end{array}$ & 2,68 & 1,087 \\
\hline $\begin{array}{l}\text { The unity of the organization is supported by loyalty, mutual trust and } \\
\text { the commitment to organization }\end{array}$ & 2,59 & 1,243 \\
\hline $\begin{array}{l}\text { The unity of organization is supported by commitment to innovation } \\
\text { and development }\end{array}$ & 2,33 & ,923 \\
\hline The unity of organization is supported by results and target orientation & 2,95 & ,943 \\
\hline The unity of organization is supported by formal rules and regulations & 2,13 & 1,155 \\
\hline $\begin{array}{l}\text { The organizational strategy is characterized by promoting personal } \\
\text { development, trust, openness and involvement }\end{array}$ & 2,38 & 1,185 \\
\hline $\begin{array}{l}\text { The organizational strategy is characterized by innovation, access to } \\
\text { new resources and defining challenges }\end{array}$ & 2,34 & ,967 \\
\hline $\begin{array}{l}\text { The organizational strategy is characterized by competition and } \\
\text { performance orientation }\end{array}$ & 2,45 & 1,116 \\
\hline $\begin{array}{l}\text { The organizational strategy is characterized by stability, efficiency, } \\
\text { coordination and trouble-free operation }\end{array}$ & 2,84 & 1,147 \\
\hline
\end{tabular}

Source: Authors' processing

Based on the data above it can be assumed that most of the companies are characterized by family atmosphere, efficient leadership, conformity in employee management, result and target orientation, and the company strategy is efficient. The responses cannot be considered homogeneous according to high values of standard deviation.

A number of researchers are studying the cultural elements of different countries. Hofstede's findings distinguish 6 cultural elements. These are the following: power gap, individualism-collectivism, masculinity-femininity, avoidance of uncertainty, permissivenessrestriction. Examining the Slovak and Hungarian data, the following differences can be observed (Hofstede, 2016, online):

- The power gap in Slovakia is higher (100) than in Hungary (46), where the distance between subordinates and leaders is high. The organizations are characterized by autocratic or oligarchic leadership, the employees accept the power of leaders;

- In Hungary (80), members of the organization act more like individuals. This value is in the middle of the scale in Slovakia (52), so employees neither work as individuals, nor we can say they work as a member of a team;

- The results of both countries (Hungary-88, Slovakia-100) reflect that organizations are more characterized by masculine features e.g. performance and success 
orientation, as well as continuous competition. Money and career are considered to be dominant values;

- In Slovakia (51) the value of avoiding insecurity is lower than in Hungary (82). The written rules and regulations play an important role in Hungarian organizations; low is the level of risk-taking and high is the level of avoiding conflict.

- The values of future orientation are high in Slovakia (77) and Hungary (58), so reliance on past data is essential; short-term thinking and focus on current issues is present in the organizations. The organizations in Slovakia are more economical and characterized by persistent work,

- According to collected data, Slovakia (28) and Hungary (31) have limited cultural values, where the ambitions and desire of employees are not met, and compliance with standards is extremely important for them.

According to Hofstede, differences can be observed in the organizations of the surveyed countries. The results of primary research show similar values in organizations of the studied countries. The organizations can be characterized by family atmosphere. Their main goal is to achieve good results. The management is efficient and result-oriented; conformity, safety and predictability gain high importance. Permanent relationships are important in the organization. The business strategy focuses on stability, efficient work and problem-free operation. The organizations operating in borderline region are influenced by the characteristics of both countries. As the respondents have set up nearly the same ranking of cultural features, the analysis was completed for both the surveyed countries.

Following the examination of cultural features, well-defined groups were created, and cluster analysis was applied. The Ward method was used to determine the number of clusters, because the variables were measured on a metric scale. The most favourable solution was the creation of four clusters. The respondents were grouped into different clusters by applying a middle-square method. The clusters created on the basis of clusters centres can be characterized as the following:

- Cluster 1 - the organizations in this cluster are result-oriented. They are characterized by effective management, which is supporting the innovation, competition and risktaking. The employees are both result and target-oriented, they prefer teamwork. The company processes are based on mutual trust and employee dedication. The organizational strategy is performance oriented and characterized by competition.

- Cluster 2 - the respondents in this group are result-oriented, the leadership style and the organizational structure is formal. The innovation and competition is supported by the company management, but it is important to have constant supervision of processes. Formal rules and regulations were set to ensure work safety and predictability. The employees have to meet high performance expectations. The organizational strategy focuses on stability, efficiency, coordination and problem-free operation. Leaders support the personal development of employees.

- Cluster 3 - friendly environment is a typical organizational feature. The management expects employees to be predictable and build strong relationships, but prefers supportive and teaching attitude. Tasks and problem-solving are realized in teams, where active participation and consensus are essential features. The companies support personal development and prefer relationships based on mutual trust. They expect high performance from their employees. The processes are result-oriented; employees are loyal and committed to company objectives. Problem-free, efficient operation with the support of employees and openness of the company is the main objective of the company strategy. 
- Cluster 4 - achieving good results is a primary goal of these companies. They have formal company structure, but they are characterized by efficient leadership. Risktaking, innovation and competition are supported by the leaders. They appreciate risktaking ability and independence of their employees, but also expect openness to novelties and uniqueness. The processes are target-oriented, based on teamwork and consensus. The employees are open to challenges and innovation. The company strategy is performance-oriented.

Based on the results of cluster analysis and the characteristics of cultural elements of groups, knowledge-sharing is mostly supported by the organizations in clusters 3 and 4 . The respondents of Cluster 3 favour the elements of supportive culture, while the respondents of Cluster 4 feel closer to characteristic features of innovation-oriented culture. It is important to mention that companies in Cluster 1 and 2 also contribute to efficiency of knowledge-sharing with the following: company environment based on trust, being open to innovation, supporting personal development of employees, as well as supporting problem-solution in teams. The distribution of sample elements into clusters is illustrated below in Graph 1.

\section{Division of respondents in clusters according to elements of corporate culture}

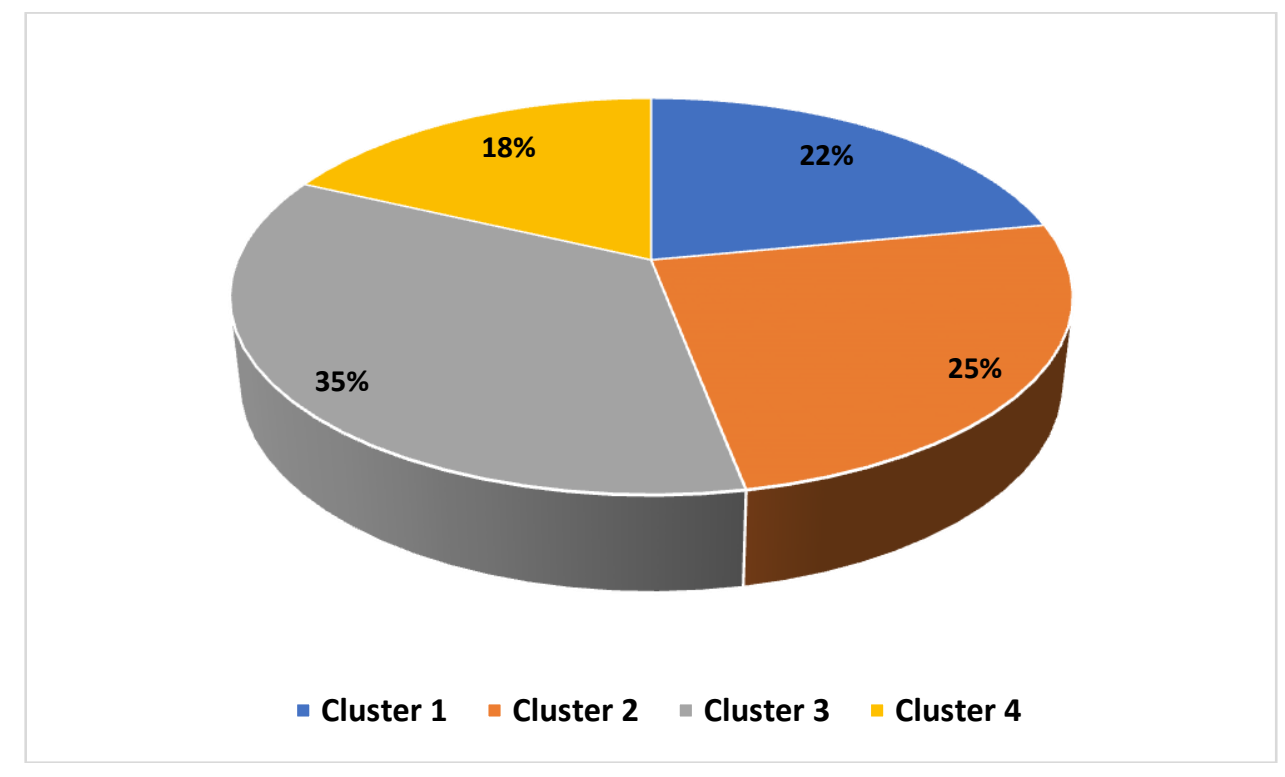

Source: Authors' processing

We have also examined, whether the clusters differ in terms of knowledge sharing characteristics. The respondents had to indicate their opinion about knowledge sharing on the Likert Scale (1-the least characteristic, 5- the most characteristic). The variables did not prove normal distribution neither in Kolmogorov-Smirnov nor the Shapiro-Wilk tests. As they have shown a skewed distribution, they had no relevant impact on F-statistics, so the analysis was possible to be conducted. The variance homogeneity was verified by the Levene-test. To analyse the relationship we applied a variance analysis. The results of the analysis are summarized in the following table. 
The variance analysis of knowledge sharing characteristics of cultural clusters

\begin{tabular}{|c|c|c|c|c|}
\hline $\begin{array}{c}\text { Specificities of organizations related to } \\
\text { knowledge sharing }\end{array}$ & \multicolumn{2}{|c|}{ Levene-test } & \multicolumn{2}{|c|}{ ANOVA } \\
\cline { 2 - 5 } & $\begin{array}{c}\text { Leven } \\
\text { statistic } \\
\text { S }\end{array}$ & Sig. & F -test & Sig. \\
\hline $\begin{array}{c}\text { Knowledge sharing plays an important role in } \\
\text { the corporate strategy }\end{array}$ & 0,616 &, 605 & 6,293 &, 000 \\
\hline $\begin{array}{c}\text { There is active knowledge transfer in the } \\
\text { organization }\end{array}$ & 0,76 &, 517 & 8,568 &, 000 \\
\hline $\begin{array}{c}\text { The organization possesses tools supporting } \\
\text { knowledge sharing }\end{array}$ & 2,101 &, 099 & 4,820 &, 003 \\
\hline $\begin{array}{c}\text { Knowledge sharing is stimulated in the } \\
\text { organization }\end{array}$ & 2,723 &, 074 & 7,789 & 7,78 \\
\end{tabular}

Source: Authors'processing

Note: Significance $p<0,05$

The Table 2 shows that significant differences can be detected between the clusters in corporate strategy supporting knowledge sharing, active knowledge transfer and the tools supporting knowledge sharing.

Following the different knowledge sharing behaviour of the clusters, we have analysed the characteristics of clusters considering their knowledge-sharing features. To simplify the presentation, the values of 5-point Likert scale have been summarized into three categories:

- the answers „no and less typical” fall into category „No”;

- the „neutral” values fall into category „Indifferent”;

- the answers ,rather” and ,very typical” fall into category „Yes”.

Based on this categorization a contingency table analysis was conducted, the results of which are shown below in Table 3.

Characteristics of knowledge sharing in cultural clusters

Table 3

\begin{tabular}{|c|c|c|c|c|c|c|c|}
\hline $\begin{array}{l}\text { Knowledge } \\
\text { sharing }\end{array}$ & Cluster & No & Indifferent & Yes & $\begin{array}{c}\text { Chi- } \\
\text { Square }\end{array}$ & Sig. & $\begin{array}{c}\text { Crammer } \\
\text { V }\end{array}$ \\
\hline \multirow{8}{*}{$\begin{array}{l}\text { Part of the } \\
\text { strategy }\end{array}$} & \multirow{2}{*}{ Cluster 1} & 24 & 42 & 72 & \multirow{8}{*}{15,69} & \multirow{8}{*}{0,016} & \multirow{8}{*}{0,113} \\
\hline & & $17,39 \%$ & $30,43 \%$ & $52,17 \%$ & & & \\
\hline & \multirow{2}{*}{ Cluster 2} & 30 & 42 & 84 & & & \\
\hline & & $19,23 \%$ & $26,92 \%$ & $53,85 \%$ & & & \\
\hline & \multirow{2}{*}{ Cluster 3} & 27 & 39 & 153 & & & \\
\hline & & $12,33 \%$ & $17,81 \%$ & $69,86 \%$ & & & \\
\hline & \multirow{2}{*}{ Cluster 4} & 18 & 27 & 60 & & & \\
\hline & & $17,14 \%$ & $25,71 \%$ & $57,14 \%$ & & & \\
\hline \multirow{7}{*}{$\begin{array}{l}\text { Active knowledge } \\
\text { transfer }\end{array}$} & \multirow{2}{*}{ Cluster 1} & 33 & 39 & 66 & \multirow{7}{*}{38,22} & \multirow{7}{*}{0} & \multirow{7}{*}{0,175} \\
\hline & & $23,91 \%$ & $28,26 \%$ & $47,83 \%$ & & & \\
\hline & \multirow{2}{*}{ Cluster 2} & 12 & 69 & 75 & & & \\
\hline & & $7,69 \%$ & $44,23 \%$ & $48,08 \%$ & & & \\
\hline & \multirow{2}{*}{ Cluster 3} & 24 & 51 & 147 & & & \\
\hline & & $10,81 \%$ & $22,97 \%$ & $66,22 \%$ & & & \\
\hline & Cluster 4 & 18 & 33 & 54 & & & \\
\hline
\end{tabular}




\begin{tabular}{|c|c|c|c|c|c|c|c|}
\hline & & $17,14 \%$ & $31,43 \%$ & $51,43 \%$ & & & \\
\hline \multirow{8}{*}{$\begin{array}{l}\text { Tools supporting } \\
\text { knowledge sharing }\end{array}$} & \multirow{2}{*}{ Cluster 1} & 78 & 27 & 33 & \multirow{8}{*}{12,749} & \multirow{8}{*}{0,047} & \multirow{8}{*}{0,102} \\
\hline & & $56,52 \%$ & $19,57 \%$ & $23,91 \%$ & & & \\
\hline & \multirow{2}{*}{ Cluster 2} & 69 & 42 & 45 & & & \\
\hline & & $44,23 \%$ & $26,92 \%$ & $28,85 \%$ & & & \\
\hline & \multirow{2}{*}{ Cluster 3} & 87 & 60 & 75 & & & \\
\hline & & $39,19 \%$ & $27,03 \%$ & $33,78 \%$ & & & \\
\hline & \multirow{2}{*}{ Cluster 4} & 39 & 27 & 36 & & & \\
\hline & & $38,24 \%$ & $26,47 \%$ & $35,29 \%$ & & & \\
\hline \multirow{8}{*}{$\begin{array}{l}\text { Stimulation of } \\
\text { knowledge sharing }\end{array}$} & \multirow{2}{*}{ Cluster 1} & 45 & 45 & 48 & \multirow{8}{*}{28,67} & \multirow{8}{*}{0} & \multirow{8}{*}{0,152} \\
\hline & & $32,61 \%$ & $32,61 \%$ & $34,78 \%$ & & & \\
\hline & \multirow{2}{*}{ Cluster 2} & 42 & 54 & 39 & & & \\
\hline & & $26,92 \%$ & $34,62 \%$ & $25,00 \%$ & & & \\
\hline & \multirow{2}{*}{ Cluster 3} & 45 & 48 & 129 & & & \\
\hline & & $20,27 \%$ & $21,62 \%$ & $58,11 \%$ & & & \\
\hline & \multirow{2}{*}{ Cluster 4} & 36 & 30 & 60 & & & \\
\hline & & $34,29 \%$ & $28,57 \%$ & $57,14 \%$ & & & \\
\hline
\end{tabular}

Source: Authors'processing

The results show that there is a significant positive but weak correlation between clusters created on the basis of organizational features associated with knowledge-sharing and Quinn's cultural elements. The results obtained by contingency table analysis also support the fact that knowledge transfer is best supported by companies classified in clusters 3 and 4 .

Knowledge management and sharing is the most effective in corporate cultures where the innovation-oriented and supportive elements of Quinn can be detected in large proportion. Based on the presented results, the hypothesis can be approved. However, we cannot ignore the fact that companies falling into other clusters are in small proportion, but they also carry the factors increasing the knowledge transfer efficiency.

\section{Conclusion}

Knowledge transfer is the most effective in those organizations, where innovationoriented and supportive elements can be detected. The results of primary research confirm the conclusions of our analysis (2013), and emphasize that companies are creative and open to change, but there is a constant competition between the employees. Based on secondary data, knowledge sharing is not always conscious and is realized through different channels. The primary results show that the signs of knowledge transfer can be clearly detected in the organizations.

The success of knowledge transfer is supported by corporate culture that is based on mutual trust and cooperation, is in constant contact with the external environmental factors, teamwork is important and the possibility for individual development is ensured. The focus of this kind of organization shifts from profit on the individual. The latter can be mainly implemented in international organizations, as most of the organizations are oriented at profit maximization. To make their knowledge exchange effective, it would be necessary to look at their employees as a priority issue. This can be achieved by training employees, creative methods of problem solution in team, ensuring constant access to information (supported by different IT solutions). 


\section{References}

Báger, G. (2008). A tudásalapú gazdaság és társadalom. Budapest: Állami Számvevőszék Fejlesztési és Módszertani Intézet. 295 p. ISBN 978-963- 87779-7-3

Bakacsi, Gy. \& Bokor, A. \& Császár, Cs. \& Gelei, A. \& Kováts, K. \& Takács, S. (2000). Stratégiai emberi erőforrás menedzsment. Budapest: KJK-KERSZÖV Jogi és Üzleti Kiadó Kft. 357 p. ISBN 63-224-543-1

Bencsik, A. \& Stifter, V. \& Sólyom, A. (2012). A tacit tudás átadásának kihívásai a Duna két partján. In Beszteri-Majoros: Változó világ: társadalmi és gazdasági útkeresés. MTA VAEB, Veszprém. 53-61 o. ISBN 978-963-7159-44-2.

Buček, M. (2010). Regionálna ekonómia a politika. Bratislava: Iura Edition. 269 p. ISBN 978-80-8078-362-4

Csath, M. (2010). Versenyképesség-menedzsment. Budapest: Nemzeti Könyvkiadó. 336 p. ISBN 978-963-1968-45-3

Dobrotková, L. (2008). Znalostná ekonomika v podmienkach globalizácie. In: Medzinárodná vedecká konferencia, Globalizácia a jej sociálno-ekonomické dôsledky. Žilina: Žilinská Univerzita v Žiline, Fakulta prevádzky a ekonomiky dopravy a spojov, pp. 93-97. ISBN 97980-969745-1-0

Dőry, T. (2005). Regionális innováció-politika: Kihívások az Európai Unióban és Magyarországon. Budapest-Pécs: Dialóg Campus Kiadó. 261 p. ISBN 963-9542-60- 1

Drjenovszky, Zs. (2005). A szervezeti kultúra és a tanuló szervezet kapcsolata I.. In Munkaügyi Szemle. 2005 június. 19-23 pp. ISSN 0541-3559.

Drucker, P. F. (1993). Post-Capitalist Society. New York: HerperCollins Publishers. 232 p. ISBN 0887306209.

Lengyel, I. (2010). Regionális gazdaságfejlesztés: Versenyképesség, klaszterek és alulról szervezödö stratégiák. Budapest: Akadémia Kiadó. 388 p. ISBN 978-963-05- 8837-9

Lucko, S. \& Trauner, B. (2005). Wissensmanagement. 7 Bausteine für die Umsetzung in der Paxis. München: Hanser Fachbuchverlag,. ISBN 978-3446400405

Lukášová, R. (2010) Organizační kultura a její změna. Praha: Grada. Publishing. 238 p. ISBN 978-80-247-2951-0.

Lundvall B. A (2004) The Economics of Knowledge and Learning. In Christensen, J., L., Lundvall, B., A. (2004): Product Inovation, Interactive Learning and Economic Performance. Emerald Group Publishing Limited. ISBN: 0-7623-1156- 8

Makó Cs. \& Moerel, H. \& Illésy, M. \& Csizmadia, P. (2008). A munkafolyamat és a foglalkoztatási viszonyok átalakítása: A tanuló gazdaság kihívásai. In Makó Csaba et. al. (szerk.): Az új utak lehetöségei a tanuló gazdaságba:. A rugalmasság és biztonság átalakuló jelentései. COMPETITIO, Center-Print Kft, Debrecen. 213 p. ISBN 963-472-796-4

Máté, D. \& Kun A. I. \& Fenyves V. (2016) The Impacts Of Trademarks And Patents On Labour Productivity In The Knowledge-Intensive Business Service Sectors AMFITEATRU ECONOMIC 18:(41) pp. 104-119. (2016)

Mesaroš, P. (2007). Vytváranie znalostnej kultúry podniku. In Ekonomika firiem 2007. Medzinárodná vedecká konferencia - Zbrojnik. SEMAFOR. Ekonomická univerzita v Bratislave, Podnikovohospodárska fakulta, Košice. ISBN 978-80-225- 2482-7. s. 521-532. 
Mura, L. \& Ključnikov, A. \& Tvaronavičiene, M., Androniceanu, A. (2017). Development Trends in Human Resource Management in Small and Medium Enterprises in the Visegrad Group. In Acta Polytechnica Hungarica, Vol. 14, No. 7, pp. 105 - 122. ISSN 1785-8860

Müller, J. \& Nessler, C. (2011): Einblicke in den interaktiv en Zusammenhang zwischen Wissensmanagement und Unternehmenskultur. In 6th Conference on Professional Knowledge Management: From Knowledge to Action, February 21-23, 2011 in Innsbruck, Austria. Lecture Notes in Informatics (Editor Ronald Maier) Vol. P-182,Gesellschaft für Informatik, Bonn, Germany, 2011,ISBN 978-3-88579-276-5, pp. 262-272.

Quinn, R.E. (1988). Beyond Rational Management: Mastering the Paradoxes and Competing Demands of High Performance. San Francisco: Jossey-Bass

Rehák, Š. (2009). Ekonómia znalostí v priestore a čase. Teoretický prehl'ad. In Region direct: the international scientific journal. Medzinárodný vedecký časopis. Banská Bystrica. Roč. 2, č. 1, s. 12-32. ISSN 1337-8473

Seres-Huszárik, E. - Józsa, L. - Tóth, Zs. (2017) Factors Determining the Development of Business Relationships in the Advertising Market. Acta polytechnica Hungarica. 2017, 14(8), 65-82. ISSN 1785-8860.

Schein, E. H. (1985, 1992). Organizational Culture and Leadership. USA: Jossey-Bass Publishers. ISBN 0-7879-6845-5.

Schultz, M. (1995) On Studying Organizational Cultures. Diagnosis and Understanding. Berlin: Walter de Gruyter. ISBN 3-11-014137-X. 196 p.

Tomka,, J. (2009) A megosztott tudás hatalom. Budapest: Harmat Kiadó Alapítvány. 284 p. ISBN 978-963-288-006-8.

Wilkesmann, U. \& Rascher, I. (2004). Lässt sich Wissen durch Datenbanken managen? Motivationale und organisationale Voraussetzungen beim Einsatz elektronischer Datenbanken. In Edeling Thomas, Jann Werner, Wagner Dieter (Hrsg.) (2004): Wissensmanagement in Politik und Verwaltung. VS Verlag für Sozialwissenschaften, Wiesbaden. 256 o. (113-129 o.) ISBN 978-3-8100-3538-7

Yi-Chun Huang \& Yen-Chun Jim Wu (2009). Intellectual Capital and Knowledge Productivity: The Taiwan Biotech Industry. In 1st Global Peter Drucker Forum, Vienna, Austria. 19-20 November 2009. 28 p. Retrieved from: < http://druckersociety.at/repository/191109/Arthur_Krupp_Saal/1400-

30/Huang_knowledge_productivity.pdf>

prof. Dr. Andrea Bencsik, CSc.

Professor

Department of Management

Faculty of Economics

J. Selye University

Bratislavská cesta 3322, 94501 Komárno, Slovak Republic

bencsika@ujs.sk

Andrea Bencsik is a professor in at Széchenyi University, Hungary and J.Selye University in Slovakia. Her research interests are knowledge -, change -, human research management, organizational behaviour. She is a member of professional scientific bodies, author and reviewer of numerous scientific papers, as well as author and editor of scientific books.

PhDr. Silvia Tóbiás Kosár, PhD. 


\section{Assistant professor}

Department of Management

Faculty of Economics

J. Selye University

Bratislavská cesta 3322, 94501 Komárno, Slovak Republic

kosars@ujs.sk

Silvia Tóbiás Kosár as an assistent professor of Department of Management at J.Selye University has participated in numerous research in the field of management, author of scientific papers and co-author of scientific papers registered in international databases. Her research interestes are: knowlege management, project management, accounting.

\section{Dr. habil Ing. Renáta Machová, PhD.}

\section{Associate professor}

Department of Management

Faculty of Economics

J. Selye University

Bratislavská cesta 3322, 94501 Komárno, Slovak Republic

machovar@ujs.sk

Machová Renáta was born on 1968, in Komárno. She started his university studies in 1989 at the University of Economics in Bratislava, Slovakia. She received the university degree from Economics and Business Trade in 1994. In 2005, he finished his Ph. D. study on the topic of international trade. She works as university teacher from 2011, nowadays she works as associate professor at the J. Selye University. Before her university works she works on international companies and at the ministry. Besides teaching, she carries out scientific researches in the field of management. The number of her publications is 112, among which approximately 30 was published in the form of books or in scientific papers, 6 books coauthor, 31 conference proceedings and 11 other professional publications has been published to present. 